\title{
Determination of User Satisfaction in Mobile Banking Services Using the Information Systems Success Model (ISSM) Perspective
}

\author{
Moh. Riky Saadilah ${ }^{1, *}$ Ratih Hurriyati ${ }^{2}$, Puspo Dewi Dirgantari ${ }^{3}$ \\ ${ }^{1}$ Universitas Pendidikan Indonesia \\ ${ }^{2}$ Universitas Pendidikan Indonesia \\ ${ }^{3}$ Uiversitas Pendidikan Indoesiai \\ *Corresponding author. Email: riky@upi.edu
}

\begin{abstract}
This study aims to determine the effect of Systems Quality, Information Quality, and Service Quality on User Satisfaction in Mobile Banking (M-Banking) users. The research method used was a quantitative approach by distributing questionnaires to 117 respondents of Mobile Banking users. Data analysis used was Partial Least Squares (PLS) where the results showed that System Quality and Information Quality affected the User Satisfaction of Mobile Banking. Increasing User Satisfaction through Information Quality and System Quality has become very important for banks. The effect of Service Quality did not directly affect User Satisfaction but was mediated by User Experience in using Mobile Banking for a long time, which can be a determining factor if the user has a positive image of the quality of Mobile Banking services.
\end{abstract}

Keywords: systems quality, information quality, service quality, mobile banking, use, user satisfaction.

\section{INTRODUCTION}

In Indonesia, Internet users are experiencing rapid growth from year to year [1]. The majority of Internet users use cell phones as their access tools [2]. This condition has been successfully exploited by most banks by launching IS-based e-channel innovations that can be directly accessed by mobile phones, smartphones, and Personal Digital Assistants (PDAs). This service is also called Mobile Banking or abbreviated as M-Banking [3, 4]. The trend in the number of banking transaction frequencies using M-Banking is increasing [5]. The success achieved by the implementation of M-Banking as a digital-based service is very interesting to study.

The technology acceptance model most widely used to measure M-Banking receipts $[3,6]$ is the Technology Acceptance Model (TAM) proposed by [7] The User Satisfaction perspective looks at the department or company that manufactures and provides M-Banking services which state that the success rate of implementing M-Banking is measured by System Quality, Information Quality, Service Quality, and Use [7].
Previous empirical studies have used the ISSM model to measure User Satisfaction [8-11]. This study aims to analyze the mediating effect of Use in MBanking. Where the results of this research are expected to provide input for managers in the banking sector regarding the factors that influence the successful implementation of M-Banking and add to the existing literature, particularly studies empirical about the successful implementation of M-Banking.

\subsection{Mobile Banking (MB)}

MB or M-Banking can be described as a channel where customers communicate with banks through mobile devices, such as cellphones, smartphones, or Personal Digital Assistants (PDAs) [3, 4]. The MB application with the SMS model requires the user's mobile device to be connected to the Global System for Mobile (GSM) network while the user API model is quite connected to the data network, using a data package or Wireless Fidelity (WiFi) connected to the Internet. 


\subsection{Information System Success Model (ISSM)}

This study adapted the ISSM model [8]. This model has six (6) constructs that are interconnected. The construct consists of quality dimensions which consist of system, information, and service. These dimensions affect Use and User Satisfaction both directly and indirectly. Figure 1 shows the measurement model of this research.

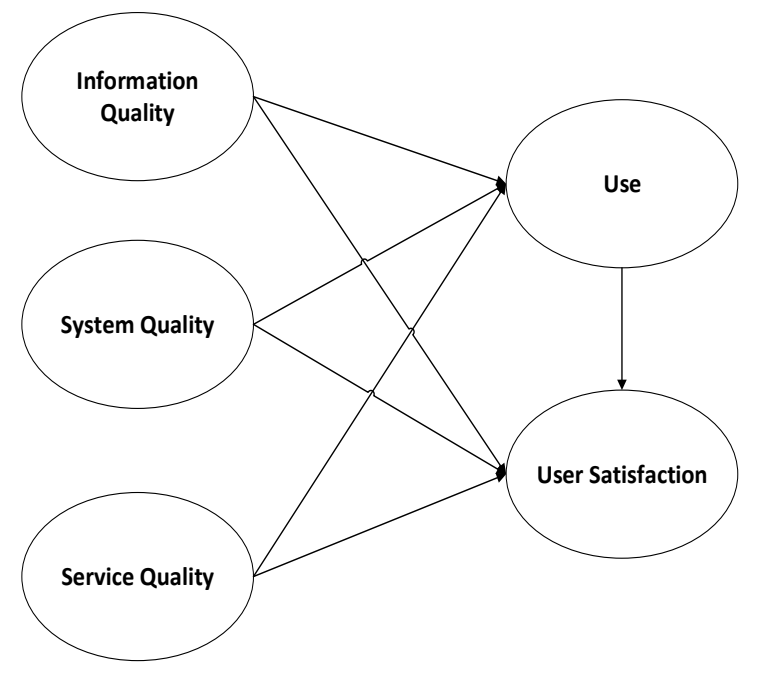

Figure 1. Measurement Model [8]

\subsection{Information Quality (IQ)}

IQ measures the quality of the output of information systems. The experience of using services during the post-implementation phases can be affected by the MB data format, such as general product and requirements for use. Where the information is irrelevant, unreliable, or obsolete, consumers may doubt the credibility of service providers and the ability to provide quality services [12-14]. Low quality of information would frustrate user experience, as making a great deal of effort to find information will impact user satisfaction level. Hence this analysis indicates the following hypothesis:

\section{H1. IQ has a positive effect on MB use.}

H2. IQ has a positive effect on MB user satisfaction.

\subsection{Systems Quality (SQ)}

As part of the consistency aspect of the system, [15] examined system reliability, system precision, accessibility, online response time, and ease of use. In particular, they include Bailey and Pearson's four measures in system efficiency, namely: ease of access, system versatility, system integration, and response time [16]. MB systems have several negative effects, including small displays, crowded keypads, limited bandwidth capacity, and other restrictions [13, 17, 18]. Poor SQ will intensify user experience because MB increases their difficulties and cannot satisfy users. A study using the meta-analysis method [19] about ISSM produced a strong conclusion that SQ was very influential on User Satisfaction and Use. SQ on MB had a positive effect on User Satisfaction [9]. Within this analysis, two hypotheses were tested:

H3. The SQ has a positive effect on MB use.

H4. The SQ has a positive effect on MB user satisfaction.

\subsection{Service Quality (SRVQ)}

A decade after the successful D\&M IS model, in the "Ten Year Update" article the SRVQ dimension was added to the [7] models. According to them, the standard of service is the total support rendered by the service providers, whereas according to Petter et al [20], it is the level of service received by system users from the Information Systems (IS) department and its support staff, such as responsiveness, reliability, conciseness, technical competence and employee empathy. In an empirical analysis of the banking sector [21, 22] SRVQ has been found to have a significant effect on user satisfaction and user emotional responses. Low SRVQ can frustrate users and low user satisfaction with MB. Therefore, the hypothesis proposed is:

H5. The SRVQ has a positive effect on MB use.

H6. SRVQ has a positive effect on MB user satisfaction.

\subsection{Use (U) dan User Satisfaction (US)}

US is the user's view of the particular computer program they use [23]. A positive experience because of the use will result in increased US. These studies used real usage by measuring the number of requests for information from users or the amount of connection time from users. Upon assessing the overall system efficiency, use and US were focused on in this study. While, as noted by [3], some MB studies concentrating on the adoption of MB does not provide a conclusion about the implications of usage. A positive experience because of the use will result in increased US. Therefore, this study suspects:

H7. Use has a positive effect on US in MB.

\section{METHODS}

Sampling in this study used the Purposive Sampling method, namely sampling with a specific purpose [24]. Because the exact number of MB users in Indonesia is unknown, the minimum sample withdrawal is 10 times the highest number of items in the model constructions used in this study [25, 26]. The highest number of items is 6 items from the SQ construct. Then the minimum sample that must be obtained is 60 respondents. The manifest variables used for the constructs SQ, IQ, and 
SRVQ in this study were adapted from research conducted by [27]. Whereas the U and US construct was adapted from a research by [27, 13]. All of these variables were translated into Indonesian and adjusted to the research object of Mobile Banking [6]. A Likert scale of 1 to 5 was used in the answers to the questions given. Data was collected electronically using Google Forms. Data were collected for four (4 days, from 19 to 23 November 2019). This study used Smart PLS 3.2.8 to evaluate items from the measurement and testing of hypotheses.

\section{RESULTS AND DISCUSSION}

\subsection{Result}

was obtained. Only 117 samples of data were declared eligible for analysis. In more detail, the profile of respondents can be seen in Table 1 .

Table 1. CHARACTERISTICS OF RESPONDENTS

\begin{tabular}{|c|l|l|l|}
\hline \multicolumn{2}{|c|}{ Total Respondent $\mathbf{n}=\mathbf{1 1 7}$} & \multicolumn{1}{|c|}{ Total } & Percentage \\
\hline \multirow{4}{*}{ Gender } & Male & 78 & $66,66 \%$ \\
\cline { 2 - 4 } & Female & 39 & $33,33 \%$ \\
\hline \multirow{5}{*}{ Age } & 17 sd 27 year & 79 & $67,52 \%$ \\
\cline { 2 - 4 } & 28 sd 38 year & 18 & $15,38 \%$ \\
\cline { 2 - 4 } & 39 sd 49 year & 18 & $15,38 \%$ \\
\cline { 2 - 4 } & $>50$ year & 2 & $1,70 \%$ \\
\hline \multirow{5}{*}{ Status } & Lecture & 10 & $8,54 \%$ \\
\cline { 2 - 4 } & Employee & 32 & $27,35 \%$ \\
\cline { 2 - 4 } & Student & 75 & $64,10 \%$ \\
\hline
\end{tabular}

The measurement model will emphasize measurements on Convergent and Discriminant Validity [28]. Convergent Validity will measure three things, namely: item reliability or question indicators on the questionnaire, Composite Reliability (CR) of the construct, and Average Variance Extracted [29]. Discriminant Validity has an aim to ensure that reflective constructs have the strongest relationship with their indicators compared to other constructs in the PLS pathway model [30].

The measuring outputs of the model are shown in Table 2 and 3 . The reliability of the successful indicators is assessed on the basis that the loadings will surpass $0.70[31,32]$ (Outer Loadings). As shown in table 2, Loadings are above 0.70. Only IQ6 and U1 items have a loading value of less than 0.7. Especially for the two (2) items removed from the model. CR results which are greater than 0.7 suggest strong internal consistency for the model [33]. Average Extracted Variance (AVE) is used to check the validity of the convergent. AVE must be above 0.50 because latent variables clarify over half the predictor variants. [29-31, $34,35]$.

Table 2. ISSM Model Measurement Results On Mb

\begin{tabular}{|c|c|c|c|c|c|}
\hline Construct & Item & Loading & $\mathbf{A V E} \mathbf{E}^{\mathbf{b}}$ & $\mathbf{C R}^{\mathrm{c}}$ & RhoA $^{d}$ \\
\hline \multirow{5}{*}{$\begin{array}{c}\text { Information } \\
\text { Quality }\end{array}$} & IQ1 & 0.834 & 0.710 & 0.924 & 0.902 \\
\hline & IQ2 & 0.829 & & & \\
\hline & IQ3 & 0.874 & & & \\
\hline & IQ4 & 0.856 & & & \\
\hline & IQ5 & 0.818 & & & \\
\hline \multirow{3}{*}{$\begin{array}{l}\text { System } \\
\text { Quality }\end{array}$} & SQ1 & 0.906 & 0.782 & 0.915 & 0.861 \\
\hline & SQ5 & 0.912 & & & \\
\hline & SQ6 & 0.833 & & & \\
\hline \multirow{4}{*}{$\begin{array}{l}\text { Service } \\
\text { Quality }\end{array}$} & SRVQ1 & 0.791 & 0.659 & 0.885 & 0.845 \\
\hline & SRVQ2 & 0.875 & & & \\
\hline & SRVQ3 & 0.855 & & & \\
\hline & SRVQ4 & 0.717 & & & \\
\hline \multirow[t]{2}{*}{ Use } & $\mathrm{U} 2$ & 0.835 & 0.766 & 0.867 & 0.744 \\
\hline & U3 & 0.913 & & & \\
\hline \multirow{3}{*}{$\begin{array}{c}\text { User } \\
\text { Satisfaction }\end{array}$} & US1 & 0.927 & 0.869 & 0.952 & 0.928 \\
\hline & US2 & 0.937 & & & \\
\hline & US3 & 0.933 & & & \\
\hline
\end{tabular}

Item issued: item indicator $<0.7$ : IQ6 and U1

The validity of the discriminant applies to two factors. At first, the square root of the AVE (diagonal element) is larger than the correlation between each pair of constructs (elements outside diagonal numbers) [29]. Table 3 shows that the square root AVE (in bold) is higher than that of a construct.

To fulfill the Fornell and Larcker criteria, this study released three items, namely SQ2, SQ3, and SQ4. This is because the AVE square value of the SQ construct is smaller than the US construct.

Second, to ensure discriminant validity, the value of loading items associated with a construct (in bold) must be greater than the value of Cross-Loadings (vertical and horizontal values of other constructs) [36-37]. Item US4 (0.761) is excluded from the model because the loading value is smaller than from SQ5 (0.782) and U3 (0.792). After removing the item, the model can meet the requirements of Cross Loadings.

Table 3. Fornell \& Larcker Measurement Results

\begin{tabular}{|c|c|c|c|c|c|}
\hline & IQ & SQ & SRVQ & U & US \\
\hline $\boldsymbol{I Q}$ & $\mathbf{0 . 8 4 3}$ & & & & \\
\hline $\boldsymbol{S Q}$ & 0.754 & $\mathbf{0 . 8 8 4}$ & & & \\
\hline $\boldsymbol{S R V Q}$ & 0.574 & 0.560 & $\mathbf{0 . 8 1 2}$ & & \\
\hline $\boldsymbol{U}$ & 0.623 & 0.750 & 0.610 & $\mathbf{0 . 8 7 5}$ & \\
\hline $\boldsymbol{U S}$ & 0.721 & 0.800 & 0.632 & 0.783 & $\mathbf{0 . 9 3 2}$ \\
\hline
\end{tabular}


Measurement tests of the measuring model show that the model has internal consistency, variable reliability, convergent validity, and strong discriminating validity. Table 4 shows the cross loadings measurement.

Table 4. Cross Loadings Measurement

\begin{tabular}{|c|c|c|c|c|c|}
\hline & IQ & SQ & SRVQ & U & US \\
\hline IQ1 & $\mathbf{0 . 8 3 4}$ & 0.689 & 0.522 & 0.562 & 0.622 \\
\hline IQ2 & $\mathbf{0 . 8 2 9}$ & 0.599 & 0.471 & 0.501 & 0.648 \\
\hline IQ3 & $\mathbf{0 . 8 7 4}$ & 0.706 & 0.523 & 0.582 & 0.651 \\
\hline IQ4 & $\mathbf{0 . 8 5 6}$ & 0.590 & 0.428 & 0.502 & 0.597 \\
\hline IQ5 & $\mathbf{0 . 8 1 8}$ & 0.579 & 0.469 & 0.466 & 0.500 \\
\hline SQ1 & 0.587 & $\mathbf{0 . 9 0 6}$ & 0.462 & 0.651 & 0.692 \\
\hline SQ5 & 0.645 & $\mathbf{0 . 9 1 2}$ & 0.448 & 0.672 & 0.745 \\
\hline SQ6 & 0.770 & $\mathbf{0 . 8 3 3}$ & 0.577 & 0.665 & 0.684 \\
\hline SRVQ1 & 0.381 & 0.294 & $\mathbf{0 . 7 9 1}$ & 0.358 & 0.380 \\
\hline SRVQ2 & 0.488 & 0.410 & $\mathbf{0 . 8 7 5}$ & 0.467 & 0.483 \\
\hline SRVQ3 & 0.360 & 0.361 & $\mathbf{0 . 8 5 5}$ & 0.414 & 0.426 \\
\hline SRVQ4 & 0.551 & 0.623 & $\mathbf{0 . 7 1 7}$ & 0.630 & 0.649 \\
\hline U2 & 0.405 & 0.546 & 0.474 & $\mathbf{0 . 8 3 5}$ & 0.569 \\
\hline U3 & 0.655 & 0.744 & 0.584 & $\mathbf{0 . 9 1 3}$ & 0.779 \\
\hline US1 & 0.624 & 0.712 & 0.582 & 0.682 & $\mathbf{0 . 9 2 7}$ \\
\hline US2 & 0.665 & 0.735 & 0.553 & 0.731 & $\mathbf{0 . 9 3 7}$ \\
\hline US3 & 0.721 & 0.786 & 0.628 & 0.772 & $\mathbf{0 . 9 3 3}$ \\
\hline & & & & & \\
\hline
\end{tabular}

In Figure 2, which is the result of measurements in this model, it can be seen that the R-Square Adjusted Model for the Use is 0.606 . This means that the ability of exogenous variables IQ, SQ, SRVQ in explaining Use is $60.6 \%$ or can be categorized as moderate [35, 38]. The R-Square Adjusted Model for US is 0.739 . This means that the ability of IQ, SQ, SRVQ, U in explaining US by $73.9 \%$ is included in the medium category [35, 38].

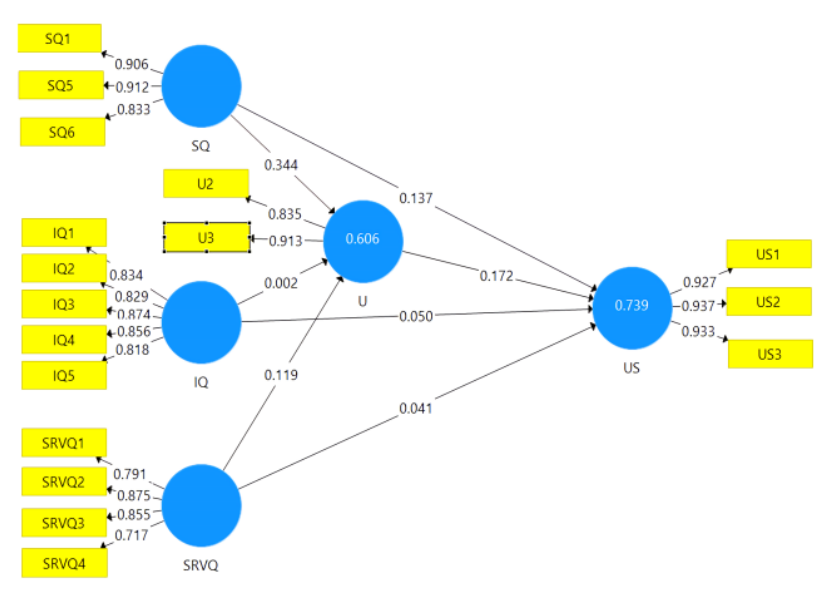

Figure 2. Statistic Model
IQ $(\beta=0.179, * * \mathrm{p}<0.05)$ shows statistical significance in explaining User Satisfaction, so that the $\mathrm{H} 2$ hypothesis is accepted. However, IQ is not statistically significant in explaining Use, so that the H1 hypothesis is rejected. The value of SQ $(\beta=0.570$, *** $\mathrm{p}<0.01)$ shows that it is statistically significant in explaining Use, so that the $\mathrm{H} 3$ hypothesis is accepted. Likewise, the significance of SQ $(\beta=0.338, * * * p$ $<0.01)$ on US means that H4 is accepted. SRVQ ( $\beta=$ 0.269 , *** $\mathrm{p}<0.01)$ shows statistical significance in explaining Use, so that the H5 hypothesis is accepted. However, IQ is not statistically significant in explaining Use, so hypothesis H6 is rejected. Use values ( $\beta=$ 0.336 , *** $\mathrm{p}<0.01)$ show statistically important to describe US. All the $\beta$ values in Table 5 are positive showing that $\mathrm{H} 2, \mathrm{H} 3, \mathrm{H} 4, \mathrm{H} 5$, and $\mathrm{H} 7$ have a positive effect on the endogenous construct of Use and US.

Table 5. Hypothesis Test Results

\begin{tabular}{|l|l|l|l|l|}
\hline \multicolumn{1}{|c|}{ Hypothesis } & \multicolumn{1}{|c|}{$\boldsymbol{\beta}$} & Result & $\mathbf{f}^{2}$ & Effect Size \\
\hline $\begin{array}{l}\text { H1: Information } \\
\text { Quality to Use }\end{array}$ & 0.039 & Rejected & 0.002 & none \\
\hline $\begin{array}{l}\text { H2:Infomation } \\
\text { Quality to User } \\
\text { Satisfaction }\end{array}$ & $0.179 * *$ & Accepted & 0.050 & small \\
\hline $\begin{array}{l}\text { H3:Sytems } \\
\text { Quality to Use }\end{array}$ & $0.570 * * *$ & Accepted & 0.344 & medium \\
\hline $\begin{array}{l}\text { H4:Sytems } \\
\text { Quality to User } \\
\text { Satisfaction }\end{array}$ & $0.338 * * *$ & Accepted & 0.137 & small \\
\hline $\begin{array}{l}\text { H5:Service } \\
\text { Quality to Use }\end{array}$ & $0.269 * * *$ & Accepted & 0.119 & small \\
\hline $\begin{array}{l}\text { H6: Service } \\
\text { Quality to User }\end{array}$ & 0.135 & Rejected & 0.041 & none \\
\hline Satisfaction & $0.336 * * *$ & Accepted & 0.172 & medium \\
\hline $\begin{array}{l}\text { H7:Use to User } \\
\text { Satisfaction }\end{array}$ & & & & \\
\hline
\end{tabular}

Notes: Effect size: $>0.350$ large; 0.150 and $\leqslant 0.350$ intermediate; 0.020 and $\leqslant 0.150$ are small $[36,39]$. Path $\beta$ : * $\mathrm{p}<0.10 ; * * \mathrm{p}<0.05$; $* * * \mathrm{p}<0.001$

Table 5 reports on the $\mathrm{f} 2$ evaluation of the structural model [40]. The effects of one structure on another were calculated by comparing the R2 values of all endogenous constructs. All organizational paths that are important to US and use in this model have a small to medium-sized impact. This research was carried out using a path model blindfolding technique (Q2) to test the predictive value. Q2 value greater than 0 suggests that the model has a predictive potential for certain endogenous constructions. On the other hand, the values 0 and below display a lack of predictive ability [31]. Within this model all Q2 values have been substantially higher than 0 (Use $=0.419$; US $=0.599)$.

Mediation analyses take place when an intermediary role plays in the third construct (mediator construct) between the two associated constructs [41, 42]. It is defined in more detail in PLS-SEM [30]. The analysis was carried out by looking at the coefficient of the significance of the $t$ value from the exogenous variable 
$\mathrm{P} 1$ to the mediator variable. The $\mathrm{P} 2$ value measures the coefficient of the significance of the $t$ value from the mediator variable to the exogenous variable. While the $\mathrm{P} 3$ value is the significance coefficient of the $t$ value from the exogenous variable to the endogenous variable (direct path). P3 value indicates a very strong significance $(p<0.01)$ between Use and US. This has fulfilled the requirements for measuring the effects of mediation [41].

From table 6 it can be seen that the mediating effect of Full Mediation occurs between the SRVQ construct and the US mediated by the Use construct.

Table 6. Analysis of Mediation Effects

\begin{tabular}{|c|c|c|c|c|c|}
\hline $\begin{array}{c}\text { Mediation } \\
\text { Effect }\end{array}$ & $\begin{array}{c}\text { Direct } \\
\text { Effect } \\
\text { (P1) }\end{array}$ & $\begin{array}{c}\text { Direct } \\
\text { Effect } \\
\text { (P2) }\end{array}$ & $\begin{array}{c}\text { Direct } \\
\text { Effect } \\
\text { (P3) }\end{array}$ & Indirect & $\begin{array}{c}\text { Interpretatio } \\
\text { n }\end{array}$ \\
\hline $\begin{array}{l}\text { IQ -->U-- } \\
>\text { US }\end{array}$ & $\begin{array}{l}0.039(0) \\
.386)\end{array}$ & $\begin{array}{l}0.336 * \\
* *(4.14 \\
5)\end{array}$ & $\begin{array}{l}0.179 * \\
*(2.108 \\
)\end{array}$ & $\begin{array}{l}0.013(0 . \\
379)\end{array}$ & $\begin{array}{l}\text { No } \\
\text { Mediation }\end{array}$ \\
\hline $\begin{array}{l}\text { SQ -->U-- } \\
>\text { US }\end{array}$ & $\begin{array}{l}0.570 * \\
* *(6.90 \\
0)\end{array}$ & $\begin{array}{l}0.336 * \\
* *(4.14 \\
5)\end{array}$ & $\begin{array}{l}0.338 * \\
* *(3.54 \\
1)\end{array}$ & $\begin{array}{l}0.192 * * * \\
(3.265)\end{array}$ & $\begin{array}{l}\text { Partial } \\
\text { Mediation }\end{array}$ \\
\hline $\begin{array}{l}\text { SRVQ--> } \\
\text { U-->US }\end{array}$ & $\begin{array}{l}0.269 * \\
* *(3.14 \\
5)\end{array}$ & $\begin{array}{l}0.336 * \\
* *(4.14 \\
5) \\
\end{array}$ & $\begin{array}{l}0.135(1 \\
.690)\end{array}$ & $\begin{array}{l}0.090 * *( \\
2.425)\end{array}$ & $\begin{array}{l}\text { Full } \\
\text { Mediation }\end{array}$ \\
\hline
\end{tabular}

\subsection{Discussion}

Based on the findings outlined in the sections above, it indicates that the proposed research model tested in this study was able to achieve a satisfactory degree of predictive power obtained by dependent constructs: Use $(60 \%)$ and User Satisfaction (73\%). SQ and IQ affected US in MB systems, which aligns with the previous study [8 11]. SQ and SRVQ affected Use, which is in line with previous research [10]. The mediation effect of Use from SRVQ to US was Full Mediation, and this result is in line with the previous study [43].

\section{CONCLUSION}

The validation of the ISSM model that is formed through SQ and IQ is proven to affect US on MB services. Banks as MB service providers must continue to improve the quality of the system according to the criteria expected by users, so that the level of use will increase. Apart from that, in the future, the quality of information must be maintained and improved. Unattractive information, inaccurate information, and language that are not easily understood are the deficiencies of the quality of information that can reduce customer satisfaction. To use MB for a long time, more responsive service quality and a solution to the disturbances experienced by users are needed.

\section{REFERENCES}

[1] Statista.com, "• Internet usage in Indonesia | Statista," 2019.

[2] J. Muller, “• Indonesia: mobile phone Internet user growth 2022 | Statista," 2020.

[3] A. A. Shaikh and H. Karjaluoto, "Mobile banking adoption: A literature review," Telemat. Informatics, vol. 32, no. 1, pp. 129-142, 2015.

[4] S. J. Barnes and B. Corbitt, "Mobile banking: concept and potential," Int. J. Mob. Commun., vol. 1, no. 3, pp. 273-288, 2003.

[5] H. Widowati, "Transaksi digital menggeser peran kantor cabang dan ATM Bank," katadata, 2019.

[6] C. Tam and T. Oliveira, "Literature review of mobile banking and individual performance," Int. J. Bank Mark., vol. 35, no. 7, pp. 1042-1065, 2017.

[7] W. H. DeLone and E. R. McLean, "The DeLone and McLean model of information systems success: A ten-year update," J. Manag. Inf. Syst., vol. 19, no. 4, pp. 9-30, 2003.

[8] K. C. Lee and N. Chung, "Understanding factors affecting trust in and satisfaction with mobile banking in Korea: A modified DeLone and McLean's model perspective," Interact. Comput., vol. 21, no. 5-6, pp. 385-392, 2009.

[9] C. Koo, Y. Wati, and N. Chung, "A study of mobile and internet banking service: Applying for IS Success Model," Asia Pacific J. Inf. Syst., vol. 23, no. 1, pp. 65-86, 2013.

[10] S. K. Sharma and M. Sharma, "Examining the role of trust and quality dimensions in the actual usage of mobile banking services: An empirical investigation,” Int. J. Inf. Manage., vol. 44, no. July 2018, pp. 65-75, 2019.

[11] C. Tam and T. Oliveira, "Understanding the impact of m-banking on individual performance: DeLone \& McLean and TTF perspective," Comput. Human Behav., vol. 61, no. August, pp. 233-244, 2016.

[12] C. M. K. Cheung, M. K. O. Lee, and N. Rabjohn, "The impact of electronic word-of-mouth: The adoption of online opinions in online customer communities," Internet Res., vol. 18, no. 3, pp. 229-247, 2008.

[13] T. Zhou, “An empirical examination of initial trust in mobile banking," Internet Res., vol. 21, no. 5, pp. 527-540, 2011.

[14] T. Zhou, "An empirical examination of continuance intention of mobile payment services," 
Decis. Support Syst., vol. 54, no. 2, pp. 1085-1091, 2013.

[15] W. H. Delone and E. R. McLean, "Information systems success: the quest for the dependent variable. Information systems research," Inst. Manag. Sci. (now INFORMS), vol. 3, no. 1, pp. 60-95., 1992.

[16] J. E. Bailey and S. Pearson, "Developing a tool for measuring computer user satisfaction." 1983.

[17] M. Chae and J. Kim, "Do size and structure matter to mobile users? An empirical study of the effects of screen size, information structure, and task complexity on user activities with standard web phones," Behav. Inf. Technol., vol. 23, no. 3, pp. 165-181, 2004.

[18] V. Zwass, "Electronic commerce and organizational innovation: Aspects and opportunities," Int. J. Electron. Commer., vol. 7, no. 3, pp. 7-37, 2003.

[19] S. Petter and E. R. McLean, "A meta-analytic assessment of the DeLone and McLean IS success model: An examination of IS success at the individual level," Inf. Manag., vol. 46, no. 3, pp. 159-166, 2009.

[20] Budiwati and Kurniasih, "Analysis of Mobile Banking (M-Banking) success using a respecification of Delone \& Mclean Information Success Model (Case Study at Permata Bank, Surakarta, Indonesia)," Int. Proc. Econ. Dev. Res., vol. 76, p. 78, 2014.

[21] S. Petter, W. DeLone, and E. McLean, "Measuring information systems success: Models, dimensions, measures, and interrelationships," Eur. J. Inf. Syst., vol. 17, no. 3, pp. 236-263, 2008.

[22] M. Ali and S. A. Raza, "Service quality perception and customer satisfaction in Islamic banks of Pakistan: the modified SERVQUAL model," Total Qual. Manag. Bus. Excell., vol. 28, no. 5-6, pp. 559-577, 2017.

[23] V. Marinkovic and V. Obradovic, "Customers' emotional reactions in the banking industry," Mark. Intell. Plan., vol. 33, no. 3, pp. 243-260, 2015.

[24] W. J. Doll and G. Torkzadeh, "The Measurement of End-User Computing Satisfaction," Source MIS Q., vol. 1213512, no. 2, pp. 259-274, 1988.

[25] I. Etikan, S. A. Musa, and R. S. Alkassim, "Comparison of convenience sampling and purposive sampling," Am. J. Theor. Appl. Stat., vol. 5, no. (1), pp. 1-4, 2016.
[26] N. Urbach and F. Ahlemann, "Structural equation modeling in information systems research using partial least squares," J. Inf. Technol. theory Appl., vol. 11, no. 2, pp. 5-40, 2010.

[27] J. H. Wu and Y. M. Wang, "Measuring KMS success: A respecification of the DeLone and McLean's model," Inf. Manag., vol. 43, no. 6, pp. 728-739, 2006.

[28] J. F. Hair, M. Sarstedt, L. Hopkins, and V. G. Kuppelwieser, "Partial least squares structural equation modeling (PLS-SEM): An emerging tool in business research," Eur. Bus. Rev., vol. 26, no. 2, pp. 106-121, 2014.

[29] C. Fornell and D. F. Larcker, "Evaluating Structural Equation Models with unobservable variables and measurement error," J. Mark. Res., vol. 18, no. 1, pp. 39-50, 1981.

[30] M. Hair, J. F., Hult, G. T. M., Ringle, C. M., \& Sarstedt, A Primer on Partial Least Squares Structural Equation Modeling (PLS-SEM) (2nd). Thousand Oaks, CA: Sage, 2017.

[31] M. Hair, J. F., Hult, G. T. M., Ringle, C. M., \& Sarstedt, A Primer on Partial Least Squares Structural Equation Modeling. 2014.

[32] J. Hulland, "Use of Partial Least Squares (PLS) in Strategic Management Research: A Review of Four Recent Studies," Strateg. Manag. J., vol. 20, no. 2, pp. 195-204, 1999.

[33] D. Gefen, D. Straub, and M.-C. Boudreau, "structural equation modeling and regression: guidelines for research practice," Commun. Assoc. Inf. Syst., vol. 4, no. October, 2000.

[34] R. P. Bagozzi and Y. Yi, "On the evaluation of structural equation models," J. Acad. Mark. Sci., vol. 16, no. 1, pp. 74-94, 1988.

[35] J. Henseler, C. M. Ringle, and R. R. Sinkovics, "The use of partial least squares path modeling in international marketing," Adv. Int. Mark., vol. 20, no. 2009, pp. 277-319, 2009.

[36] W. W. Chin, "the partial least squares approach to structural modeling," Mod. Methods Bus. Res., no. JANUARY 1998, pp. 295-336, 1998.

[37] O. Götz, K. Liehr-Gobbers, and M. Krafft, Evaluation of structural equation models using the partial least squares (PLS) approach. In Vinzi, V.E, Chin, W.W., Henseler,J. \& Wang, H. (eds). 2010.

[38] J. F. Hair, C. M. Ringle, and M. Sarstedt, "PLSSEM: Indeed a silver bullet," J. Mark. Theory Pract., vol. 19, no. 2, pp. 139-151, 2011. 
[39] J. Cohen, Statistical Power Analysis for the Behavioral Sciences 2nd. 1988.

[40] K. K. K.-K. Wong, "Partial Least Squares Structural Equation Modeling (PLS-SEM) techniques using SmartPLS," Mark. Bull., vol. 24, no. 1, pp. 1-32, 2013.

[41] Reuben M. Baron and David A. Kenny, "The moderator-mediator variable distinction in social psychological research: conceptual, strategic, and statistical considerations," J. Pers. Soc. Psychol., vol. 51, no. 6, pp. 1173-1182, 1986.
[42] X. Zhao, J. G. Lynch, and Q. Chen, "Reconsidering baron and kenny: myths and truths about mediation analysis," J. Consum. Res., vol. 37, no. 2, pp. 197206, 2010.

[43] P. Keikhosrokiani, N. Mustaffa, N. Zakaria, and R. Abdullah, "Assessment of a medical information system: the mediating role of use and user satisfaction on the success of human interaction with the mobile healthcare system (iHeart)," Cogn. Technol. Work, vol. 22, no. 2, pp. 281-305, 2020. 